ISSN 0258-7122 (Print), 2408-8293 (Online)

Bangladesh J. Agril. Res. 41(1): 163-171, March 2016

\title{
NITROGEN FIXATING ABILITY OF MUNGBEAN GENOTYPES UNDER DIFFERENT LEVELS OF NITROGEN APPLICATION
}

\author{
M. A. RAZZAQUE ${ }^{1}$, M. M. HAQUE ${ }^{2}$, M. A. KARIM ${ }^{3}$ \\ AND A. R. M. SOLAIMAN ${ }^{4}$
}

\begin{abstract}
A pot culture experiment was conducted at the Bangabandhu Sheikh Mujibur Rahman Agricultural University (BSMRAU), Gazipur during kharif II, 2012 to evaluate the nodulation, biological nitrogen fixation and yield potential of genotypes of mungbean under varying levels of $\mathrm{N}$ application. There were 10 mungbean genotypes viz. IPSA 12, GK 27, IPSA 3, IPSA 5, ACC12890055, GK 63, ACC12890053, BU mug 4, BARI Mung 6 and Binamoog 5, each genotype treated with six levels of $\mathrm{N}\left(0,20,40,60,80\right.$ and $\left.100 \mathrm{~kg} \mathrm{~N} \mathrm{ha}^{-1}\right)$. Among the genotypes, the IPSA 12 at $40 \mathrm{~kg} \mathrm{~N}^{-1}$ produced the maximum number of nodules (14.54 plant $\left.^{-1}\right)$ as well as the highest nitrogen fixation $\left(2.684 \mu \mathrm{mol} \mathrm{C}_{2} \mathrm{H}_{4}\right)$. This resulted in the highest seed yield (14.22 $\left.\mathrm{g} \mathrm{plant}^{-1}\right)$. The genotype ACC12890053 recorded the lowest nodulation $\left(6\right.$ plant $\left.^{-1}\right)$, nitrogen fixation (1.134) and seed yield (7.33 g plant $\left.^{-1}\right)$.
\end{abstract}

Keywords: Genotypic variability, Nitrogen fixation, Yield.

\section{Introduction}

Mungbean is one of the most important pulse crops in Bangladesh. It is now well agreed that despite nitrogen fixation, $\mathrm{N}$ alimentation in legumes is a limiting factor in terms of either quantitative (seed) or qualitative (N) yields. Generally, young plants meet up their initial nitrogen requirements through soil mineral nitrogen. After nodules have been established, $\mathrm{N}_{2}$ fixation succeeds to assimilation, reaches peak at pod developing stage and declines thereafter (Jensen, 1987). Later, most of the seed filling is achieved by the redistribution of $\mathrm{N}$ from vegetative plant organs to the developing seeds (Sagan et al., 1993). However, nitrogen fixation in plants itself is an energy expensive process. To reduce one molecule of atmospheric $\mathrm{N}_{2}$ to $\mathrm{NH}_{4}$ about 15 ATP energies are required (Poehlman, 1991). Atmospheric nitrogen fixation depends on plant age and presence of appropriate nitrogen fixing bacteria (Sagan et al., 1993). Contrary, presence of high mineral nitrogen in the soil inhibits atmospheric nitrogen fixation in grain legumes (Minchin et al., 1989; Walsh and Corroll, 1992).

The seed yield of mungbean is low in Bangladesh compared with the yield potential (Hossain et al., 2009). One of the major limitations of mungbean productivity is low soil fertility with a very low to low soil $\mathrm{N}$ nutrients.

${ }^{1}$ Senior Scientific Officer, T\&C, Bangladesh Agricultural Research Institute (BARI), Gazipur, ${ }^{2 \& 3}$ Professor, Department of Agronomy, Bangabandhu Sheikh Mujibur Rahman Agricultural University (BSMRAU), ${ }^{4}$ Professor, Department of Soil Science, BSMRAU, Gazipur, Bangladesh. 
High yield of mungbean in low fertile soil is not possible without a supply of substantial amount of nitrogen in the crop. One option for obtaining nitrogen, at least without relying on a soil source, is to take full advantage of those mungbean genotypes that can symbiotically fix more atmospheric $\mathrm{N}_{2}$. In fixing more atmospheric $\mathrm{N}_{2}$, some of the carbon fixed by the plant is used to provide the energy required for reduction of $\mathrm{N}_{2}$ to $\mathrm{NH}_{3}$ organic molecules. Although this process is energetically expensive, it might be very effective in low nitrogen environments where assimilated carbon is abundant relative to nitrogen (Sinclair and Vadez, 2002). The present study was therefore, undertaken to evaluate the nodulation, nitrogen fixation and yield of different genotypes of mungbean at varying levels of $\mathrm{N}$ application to soil.

\section{Materials and Method}

The pot culture experiment was conducted at the Bangabandhu Sheikh Mujibur Rahman Agricultural University (BSMRAU), Gazipur during kharif II season of 2012. The soil was sandy loam having $6.9 \mathrm{pH}, 0.538 \%$ organic matter, $0.05 \% \mathrm{~N}$, $0.16 \mathrm{mg} \mathrm{kg}^{-1} \mathrm{P}, 0.85 \mathrm{meq} \% \mathrm{~K}$, and $0.70 \mathrm{mg} \mathrm{kg}^{-1}$ the Rhizobium count was $4.55 \mathrm{x}$ $10^{8} \mathrm{~g}$ soil. Each pot containing $12 \mathrm{~kg}$ soil was fertilized $25 \mathrm{~kg}$ P and $32 \mathrm{~kg} \mathrm{~K} \mathrm{ha}^{-1}$ in the form of triple super phosphate and muriate of potash, respectively and mixed thoroughly with soil. The experiment was laid out in completely randomized design (CRD) with ten mungbean genotypes and six nitrogen levels, each replicated four times. Ten mungbean genotypes were (IPSA 12, GK 27, IPSA 3, IPSA5, ACC12890055, GK 63, ACC12890053, BU mug 4, BARI Mung 6 and Binamoog 5). The $\mathrm{N}$ levels were $0,20,40,60,80$ and $100 \mathrm{~kg} \mathrm{~N}^{-1}$ and applied at 15 days after sowing.

Seeds were sown on 22 August, 2012. At first trifoliate stage, the plants were thinned and maintained one plant per pot. All agronomic management and plant protection measures were kept uniform during the whole growing period of mungbean. Data on nodulation, biological nitrogen fixation, yield and yield components were recorded. The pots were weeded manually throughout the growing season. The crop was harvested at full maturity. Harvesting was done twice one on 31 October and another on 13 November, 2010. Nodulation was counted at pod developing stage. For determination of $\mathrm{N}_{2}$ fixation, nitrogen activity was assessed by measuring acetylene reduction assay (ARA) in a gas chromotograph. Mungbean plant samples were collected and brought immediately to the laboratory. Soil was removed from the roots and nodules remained intact with the plant. Roots were separated from the shoot at the cotyledonary node. Then the roots of the plants in each pot were individually placed in conical flask and were sealed with air tight rubber septum. Ten percent of the air in the flask was replaced with acetylene gas. One $\mathrm{ml}$ of gas sample was collected from each flask with a disposable $1 \mathrm{ml}$ syringe at 5 and 35 minutes after incubation and 
immediately injected in the gas chromotograph (Shimadzu, GC-8A) fitted with a flame ionization detector and a stainless steel column (3 MM DIA, $102 \mathrm{~m}$ length). The column was fitted with porapak-R, 100-200 mesh. The column and injector temperature was $60^{\circ} \mathrm{C}$. All gases used from cylinder were of purity grade in which the following flow rates were maintained: $\mathrm{H}_{2} 20 \mathrm{ml} / \mathrm{min}$. air $45 \mathrm{ml} / \mathrm{min}, \mathrm{N}_{2} 30$ $\mathrm{ml} / \mathrm{min}$. $\mathrm{N}_{2}$ was used as carrier gas. Ethylene and acetylene gases were separated in the column, detected in flame ionization detector and finally the peaks were recorded on the recorder (model Shimadzu, R-11).

The amount of ethylene was measured using the following formula:

$\frac{(\mathrm{b}-\mathrm{a}) \times \text { vol. of conical flask x } 60}{30}=\mathrm{mol} \mathrm{C}_{2} \mathrm{H}_{4} / \mathrm{plant} / \mathrm{hr}$

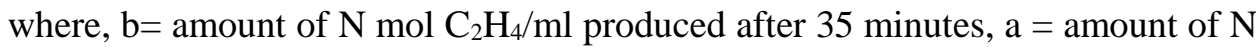

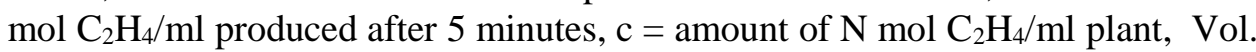
of conical flask $=$ Volume determined by subtracting root fresh weight from total water weight in the flask. After determination of ARA, roots were separated from the nodules and then nodule number and weight were recorded. Microsoft EXCEL and MSTAT-C software programs were used to perform statistical analysis of the data. Mean separation was done at $5 \%$ level of probability by DMRT.

\section{Results and Discussion}

\section{Nodule number}

At pod developing stage mungbean nodule number was counted because at this stage it reaches peak (Murakami et al., 1990). Nodules with a red or pink region usually are active in nitrogen fixation and are said to be effective, whereas nodules which are white or greenish brown are not effective and said to be senescing. Number of nodules of mungbean genotype was lower at no nitrogen application, but application of $40 \mathrm{~kg} \mathrm{~N} \mathrm{ha}^{-1}$ gave the maximum number of nodules per plant (Fig. 1). It is conceivable that the fertilizer $\mathrm{N}$ stimulated plant establishment and early growth and might have improved nodulation through positive effect on seedling roots (Akbari et al., 2008). Rate of nitrogen fixation is trivial at beginning of growing season and bacteria do not supply any nitrogen to the seedlings. Therefore, seedlings need starter dose of nitrogen either from mineral or chemical fertilizers (Patra and Bhuttacharyya, 1997). Results revealed that application of nitrogen beyond $40 \mathrm{~kg} \mathrm{~N}^{-1}$ reduced nodule number. Nitrogen nutrition inhibits nitrogen fixation in legumes as it is energy expensive processes resulting in the substantial consumption of carbohydrates in the nodules which is detrimental to development of other parts of plants (Warenbourg and Roumet, 1989). However, the mungbean genotype IPSA 12 was found most efficient in maintaining higher nodule number throughout the growing season. 


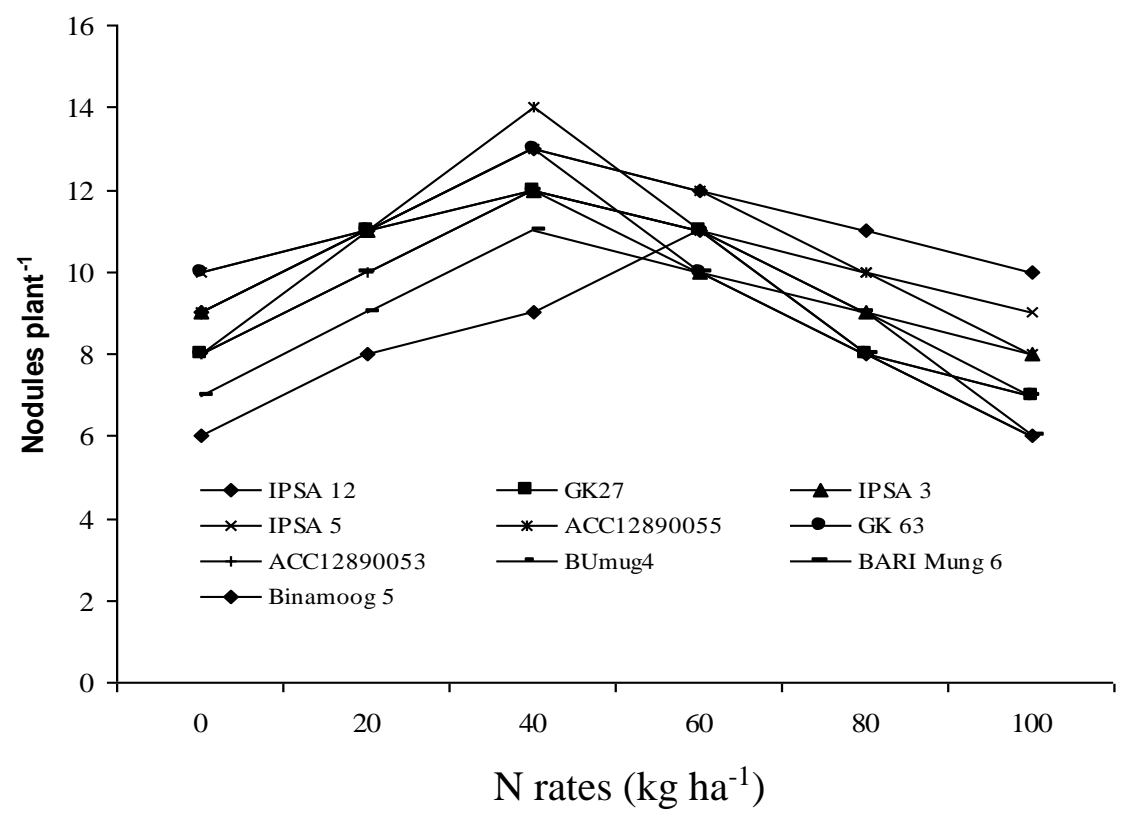

Fig.1. Nodule number of mungbean genotypes as at different levels of $\mathrm{N}$ application.

\section{Nitrogen fixation}

There was a wide variability among the mungbean genotypes in the rate of $\mathrm{N}_{2}$ fixation measured by acetylene reduction assay (ARA) using gas chromatograph at pod developing stage. The genotype also differed in $\mathrm{N}_{2}$ fixation under variable $\mathrm{N}$ levels where $\mathrm{N}_{2}$ fixation in IPSA 12 increased progressively with the increase of fertilizer $\mathrm{N}$ rates (Fig. 2). Thus the highest ARA value $\left(2.684 \mu \mathrm{mol} \mathrm{C}_{2} \mathrm{H}_{4}\right.$ plant $^{-}$ ${ }^{1}$ hour ${ }^{-1}$ ) was recorded at $40 \mathrm{~kg} \mathrm{~N}$ in IPSA 12 at pod developing stage. Contrary, the genotype ACC12890053 was less responsive to $\mathrm{N}_{2}$ fixation at control condition (no nitrogen). Higher nitrogen level inhibits nitrogen fixation of mungbean plant because nitrogen fixing bacteria consume nutrient easily from soil. These results are in accordance with other results that there exists evidence in genetic variability in $\mathrm{N}_{2}$ fixation among common bean (Devi et al., 2013), soybean (Sinclair et al., 2000) and peanut (Devi et al., 2010). Out of the five mungbean genotypes, IPSA 12 was of particular importance because of its maintaining higher ARA value $\left(2.684 \mu \mathrm{mol} \mathrm{C}_{2} \mathrm{H}_{4}\right.$ plant $^{-1}$ hour $\left.^{-1}\right)$ at $40 \mathrm{~kg} \mathrm{~N} \mathrm{ha}^{-1}$ and lower ARA value $(1.134 \mu \mathrm{mol}$ $\mathrm{C}_{2} \mathrm{H}_{4}$ plant $^{-1}$ hour $^{-1}$ ) was recorded in genotype ACC12890053. 


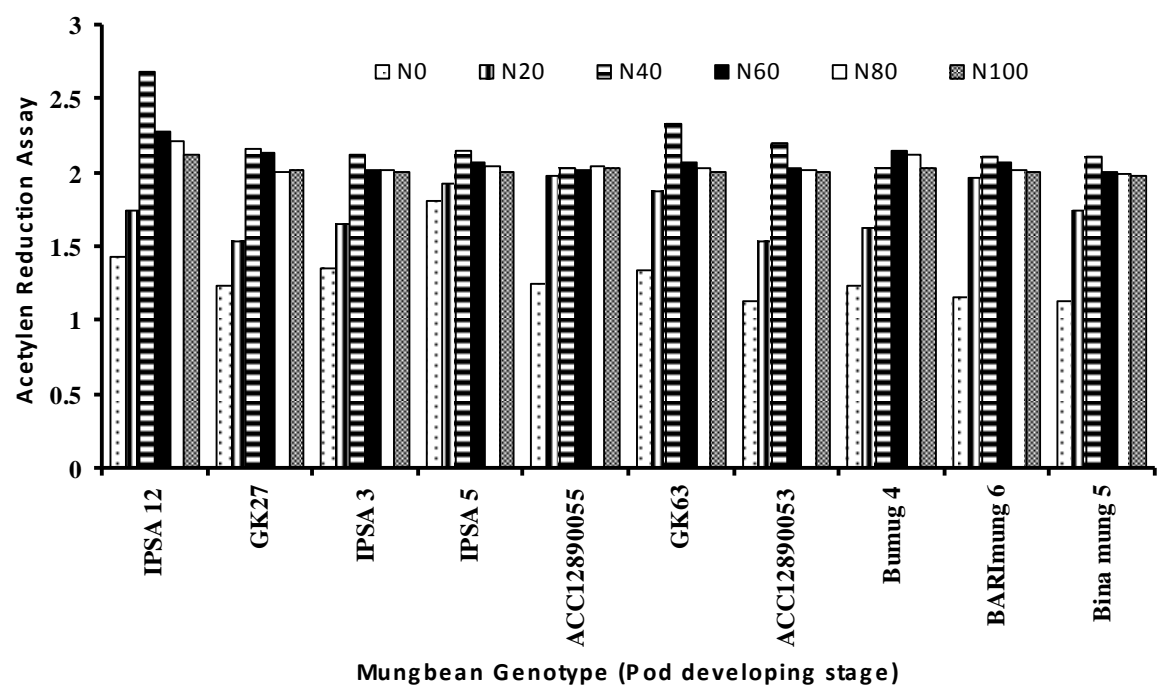

Fig. 2. Biological nitrogen fixation (Acetylene Reduction Assay micro mol/ $\mathrm{C}_{2} \mathrm{H}_{4} /$ plant/ hour) of mungbean genotypes at different levels of $\mathrm{N}$ application.

\section{Pods per plant}

Number of pods per plant of mungbean genotypes was significantly influenced by $\mathrm{N}$ levels. Increasing nitrogen level led to an increase in pods plant ${ }^{-1}$ up to $40 \mathrm{~kg} \mathrm{~N}$ $\mathrm{ha}^{-1}$ and thereafter the number decreased with the increasing $\mathrm{N}$ rates (Table 1). This result is in line with the findings of Patra and Patel (1991) who reported that number of pods per plant of mungbean increased with application of nitrogen fertilizer and excess application reduced pod number of mungbean. There were genotypic variations in pod development where the genotype IPSA 12 produced the highest number of pods (30.2) and the lowest number of pods per plant (18.9) was recorded in genotype BARI Mung 6 in $\mathrm{N}$ control condition. This means that mungbean genotypes require additional $\mathrm{N}$ for better pod development although it is capable to fix atmospheric $\mathrm{N}$ through rhizobium species living in root nodules (Anjum et al., 2006).

\section{Seeds per pod}

Interaction effect of genotype and nitrogen was not significant but genotype had significant effects on seeds per pod of mungbean (Table 2). The highest number of seeds per pod (12.4) was obtained with IPSA 12 and the lowest seed per pod (10.3) was recorded with BARI Mung 6. These findings agree with Asaduzzaman et al. (2008) who reported that nitrogen level had no significant effect on seeds per pod. The number of seeds per pod is mostly genetically controlled, but its number may 
be regulated by canopy photosynthesis during pod developing stage. Seed number also may be limited by the activity of the source (Akther, 2005). During seed filling, the ability of the individual seed to utilize, assimilate and determine number of seeds per pod is important and limitation of assimilate reduces the seeds per pod (Jenner et al., 1992).

Table 1. Number of pods per plant of mungbean genotype as affected by $\mathrm{N}$ rates.

\begin{tabular}{l|c|c|c|c|c|c|c}
\hline \multirow{2}{*}{ Genotypes } & \multicolumn{7}{|c|}{$\mathrm{N}$ rates $\left(\mathrm{kg} \mathrm{ha}^{-1}\right)$} \\
\cline { 2 - 8 } & 0 & 20 & 40 & 60 & 80 & 100 & Mean \\
\hline IPSA 12 & $22.0 \mathrm{cA}$ & $24.8 \mathrm{bcA}$ & $30.2 \mathrm{aA}$ & $27.5 \mathrm{bA}$ & $26.7 \mathrm{bA}$ & $22.7 \mathrm{cA}$ & 25.6 \\
GK 27 & $20.0 \mathrm{bA}$ & $22.5 \mathrm{abAB}$ & $23.5 \mathrm{aC}$ & $23.6 \mathrm{aB}$ & $22.3 \mathrm{abB}$ & $19.7 \mathrm{bB}$ & 21.9 \\
IPSA 3 & $19.7 \mathrm{cAB}$ & $22.7 \mathrm{bAB}$ & $25.2 \mathrm{aB}$ & $23.2 \mathrm{bB}$ & $22.5 \mathrm{bB}$ & $20.3 \mathrm{bcB}$ & 22.2 \\
IPSA 5 & $21.8 \mathrm{bcA}$ & $25.3 \mathrm{aA}$ & $27.5 \mathrm{aB}$ & $26.3 \mathrm{aA}$ & $26.0 \mathrm{aA}$ & $23.7 \mathrm{bA}$ & 25.0 \\
ACC12890055 & $20.7 \mathrm{cA}$ & $23.0 \mathrm{abAB}$ & $25.0 \mathrm{aB}$ & $23.2 \mathrm{abB}$ & $21.7 \mathrm{bB}$ & $20.8 \mathrm{bcB}$ & 22.3 \\
GK 63 & $18.8 \mathrm{cB}$ & $21.3 \mathrm{bB}$ & $23.3 \mathrm{aC}$ & $21.6 \mathrm{bC}$ & $22.33 \mathrm{bB}$ & $16.7 \mathrm{cC}$ & 20.6 \\
ACC12890053 & $20.3 \mathrm{cA}$ & $22.0 \mathrm{bcAB}$ & $25.8 \mathrm{aB}$ & $22.7 \mathrm{bC}$ & $22.0 \mathrm{bB}$ & $22.7 \mathrm{bA}$ & 22.5 \\
BU mug 4 & $19.0 \mathrm{cAB}$ & $22.0 \mathrm{bAB}$ & $24.2 \mathrm{aC}$ & $25.7 \mathrm{aAB}$ & $21.8 \mathrm{bBC}$ & $21.0 \mathrm{bcAB}$ & 22.2 \\
BARI Mung 6 & $18.9 \mathrm{cB}$ & $20.5 \mathrm{bB}$ & $23.3 \mathrm{aC}$ & $22.5 \mathrm{abC}$ & $22.3 \mathrm{aB}$ & $20.8 \mathrm{bBC}$ & 21.4 \\
Binamoog 5 & $16.8 \mathrm{dC}$ & $19.8 \mathrm{cC}$ & $24.8 \mathrm{aC}$ & $23.3 \mathrm{aB}$ & $21.5 \mathrm{bB}$ & $17.7 \mathrm{dC}$ & 20.6 \\
\hline Mean & 19.7 & 22.3 & 25.3 & 23.6 & 22.9 & 20.5 & \\
\hline
\end{tabular}

Means followed by same small letter(s) (row) and capital letter(s) (column) did not differ significantly at $5 \%$ level of probability by DMRT.

Table 2. Number of seeds per pod of mungbean genotype as affected by $\mathrm{N}$ rates.

\begin{tabular}{l|c|c|c|c|c|c|c}
\hline \multirow{2}{*}{ Genotype } & \multicolumn{7}{|c|}{$\mathrm{N}$ rates $\left(\mathrm{kg} \mathrm{ha}^{-1}\right)$} \\
\cline { 2 - 8 } & 0 & 20 & 40 & 60 & 80 & 100 & Mean \\
\hline IPSA 12 & $12.40 \mathrm{~A}$ & $12.33 \mathrm{~A}$ & $12.03 \mathrm{~A}$ & $12.13 \mathrm{~A}$ & $11.66 \mathrm{~A}$ & $11.83 \mathrm{~A}$ & 12.06 \\
GK-27 & $10.93 \mathrm{~A}$ & $11.11 \mathrm{~A}$ & $10.76 \mathrm{~B}$ & $10.85 \mathrm{~A}$ & $10.76 \mathrm{~B}$ & $10.66 \mathrm{~B}$ & 1084 \\
IPSA 3 & $11.65 \mathrm{~A}$ & $11.20 \mathrm{~A}$ & $11.08 \mathrm{~A}$ & $11.91 \mathrm{~A}$ & $11.38 \mathrm{~A}$ & $11.05 \mathrm{~A}$ & 11.38 \\
IPSA 5 & $11.46 \mathrm{~A}$ & $12.15 \mathrm{~A}$ & $11.96 \mathrm{~A}$ & $11.98 \mathrm{~A}$ & $11.60 \mathrm{~A}$ & $11.86 \mathrm{~A}$ & 11.83 \\
ACC12890055 & $10.60 \mathrm{~B}$ & $11.20 \mathrm{~A}$ & $11.20 \mathrm{~A}$ & $11.16 \mathrm{~A}$ & $11.00 \mathrm{~A}$ & $11.05 \mathrm{~A}$ & 11.03 \\
GK-63 & $10.83 \mathrm{~B}$ & $11.23 \mathrm{~A}$ & $11.36 \mathrm{~A}$ & $11.20 \mathrm{~A}$ & $10.83 \mathrm{~A}$ & $10.23 \mathrm{~A}$ & 10.95 \\
ACC12890053 & $10.40 \mathrm{~B}$ & $11.65 \mathrm{~A}$ & $10.66 \mathrm{~B}$ & $11.25 \mathrm{~A}$ & $11.23 \mathrm{~A}$ & $10.40 \mathrm{~B}$ & 10.93 \\
BU mug 4 & $10.20 \mathrm{~B}$ & $10.84 \mathrm{~A}$ & $11.15 \mathrm{~A}$ & $10.65 \mathrm{~B}$ & $11.06 \mathrm{~A}$ & $11.20 \mathrm{~A}$ & 10.85 \\
BARI Mung 6 & $10.30 \mathrm{~B}$ & $10.76 \mathrm{~A}$ & $11.01 \mathrm{~A}$ & $10.75 \mathrm{~B}$ & $11.40 \mathrm{~A}$ & $11.11 \mathrm{~A}$ & 10.88 \\
Binamoog 5 & $11.40 \mathrm{~A}$ & $11.28 \mathrm{~A}$ & $11.13 \mathrm{~A}$ & $10.73 \mathrm{~B}$ & $11.10 \mathrm{~A}$ & $11.54 \mathrm{~A}$ & 11.19 \\
\hline Mean & 11.02 & 11.37 & 11.23 & 11.26 & 11.20 & 10.09 & \\
\hline
\end{tabular}

Means followed by same capital letter(s) (column) did not differ significantly at $5 \%$ level of probability by DMRT. 


\section{0 - Seed weight}

Thousand seed weight was not affected significantly by $\mathrm{N}$ fertilizer application as it is largely governed by genetic factors. Thus 1000 -seed weight varied with the mungbean genotypes where the maximum 1000 -seed weight $(50.2 \mathrm{~g})$ was recorded in GK 27 at control and the lowest seed weight (34.2 g) was recorded in ACC12890053 at $20 \mathrm{~kg} \mathrm{Nha}^{-1}$ (Table 3). The genotype which produced lower number of seeds pod $^{-1}$ showed higher seed weight.

Table 3. Thousand seed weight (g) of mungbean genotypes as affected by $\mathrm{N}$ rates

\begin{tabular}{|c|c|c|c|c|c|c|c|}
\hline \multirow[t]{2}{*}{ Genotype } & \multicolumn{6}{|c|}{$\mathrm{N}$ rates $\left(\mathrm{kg} \mathrm{ha}^{-1}\right)$} & \multirow[b]{2}{*}{ Mean } \\
\hline & 0 & 20 & 40 & 60 & 80 & 100 & \\
\hline IPSA 12 & 41.5 & 38.8 & 38.7 & 39.2 & 40.7 & 40.3 & 39.9 \\
\hline GK-27 & 50.2 & 49.4 & 49.9 & 49.9 & 49.7 & 49.8 & 48.1 \\
\hline IPSA 3 & 47.1 & 47.7 & 46.5 & 47.8 & 45.5 & 46.1 & 46.8 \\
\hline IPSA 5 & 38.5 & 38.1 & 39.5 & 41.5 & 41.0 & 36.8 & 39.2 \\
\hline ACC12890055 & 43.7 & 46.2 & 45.7 & 43.9 & 45.9 & 42.9 & 44.7 \\
\hline GK-63 & 49.8 & 50.1 & 49.9 & 49.4 & 49.6 & 49.7 & 49.7 \\
\hline ACC12890053 & 34.7 & 34.2 & 35.8 & 34.9 & 37.7 & 34.5 & 35.3 \\
\hline BU mug 4 & 46.1 & 43.4 & 41.6 & 40.3 & 43.5 & 40.8 & 42.6 \\
\hline BARI Mung 6 & 49.3 & 48.9 & 48.9 & 50.0 & 49.0 & 48.6 & 49.1 \\
\hline Binamoog 5 & 39.0 & 40.3 & 37.2 & 37.0 & 40.7 & 41.1 & 39.2 \\
\hline Mean & 44.0 & 43.7 & 43.4 & 43.4 & 44.3 & 43.1 & \\
\hline
\end{tabular}

Means without letter did not differ significantly at 5\% level of probability by DMRT.

\section{Seed yield}

Per plant seed yield of mungbean was significantly affected by genotypes and $\mathrm{N}$ fertilizer application. The yield varied from $7.33 \mathrm{~g}$ to $14.22 \mathrm{~g} \mathrm{plant}^{-1}$ (Table 4) and it was the highest in IPSA 12 grown with $40 \mathrm{~kg} \mathrm{~N} \mathrm{ha}^{-1}$ and the lowest in ACC12890053 under control condition. There was a general trend of increased seed yield with the increase of $\mathrm{N}$ fertilizer up to $40 \mathrm{~kg} \mathrm{~N} \mathrm{ha}^{-1}$ and thereafter the yield decreased with higher $\mathrm{N}$ doses. This finding agrees with Biswas and Hamid (1989) and Mitra and Ghildiyal (1988) who separated that application of N fertilizer enhanced nodulation, nitrogen fixation and consequently improved yield components of mungbean genotype. 
Table 4. Seed yield $\left(\mathrm{g} \mathrm{plant}^{-1}\right.$ ) of mungbean genotypes as affected by $\mathbf{N}$ rates.

\begin{tabular}{l|c|c|c|c|c|c|c}
\hline \multirow{2}{*}{ Genotype } & \multicolumn{7}{c}{$\mathrm{N}$ rates $\left(\mathrm{kg} \mathrm{ha}^{-1}\right)$} \\
\cline { 2 - 8 } & 0 & 20 & 40 & 60 & 80 & 100 & Mean \\
\hline IPSA 12 & $11.32 \mathrm{Ac}$ & $11.87 \mathrm{Ac}$ & $14.22 \mathrm{Aa}$ & $12.87 \mathrm{Ab}$ & $12.41 \mathrm{Ab}$ & $10.80 \mathrm{Ac}$ & 12.25 \\
GK-27 & $10.97 \mathrm{Ab}$ & $12.34 \mathrm{Aa}$ & $12.61 \mathrm{Ba}$ & $12.80 \mathrm{Aa}$ & $11.94 \mathrm{Ab}$ & $10.43 \mathrm{Ab}$ & 11.85 \\
IPSA 3 & $10.78 \mathrm{Abc}$ & $11.83 \mathrm{Ab}$ & $13.32 \mathrm{ABa}$ & $12.82 \mathrm{Aa}$ & $11.65 \mathrm{Ab}$ & $10.35 \mathrm{Ac}$ & 11.79 \\
IPSA 5 & $9.60 \mathrm{Bc}$ & $11.72 \mathrm{Ab}$ & $13.64 \mathrm{Aa}$ & $12.45 \mathrm{Aa}$ & $12.36 \mathrm{Aa}$ & $10.10 \mathrm{Abc}$ & 11.64 \\
ACC12890055 & $9.33 \mathrm{Bc}$ & $11.90 \mathrm{Aab}$ & $12.29 \mathrm{Ba}$ & $11.81 \mathrm{Bab}$ & $10.93 \mathrm{Bb}$ & $9.87 \mathrm{ABb}$ & 11.02 \\
GK-63 & $10.06 \mathrm{Bb}$ & $12.00 \mathrm{Aa}$ & $13.09 \mathrm{Ba}$ & $12.20 \mathrm{Ba}$ & $11.99 \mathrm{Aa}$ & $9.23 \mathrm{ABb}$ & 11.43 \\
ACC12890053 & $7.33 \mathrm{Dcd}$ & $8.49 \mathrm{Db}$ & $9.60 \mathrm{Ca}$ & $9.12 \mathrm{Cab}$ & $9.31 \mathrm{BCab}$ & $7.95 \mathrm{Cc}$ & 8.63 \\
BU mug 4 & $8.93 \mathrm{Bbc}$ & $10.35 \mathrm{Bab}$ & $10.85 \mathrm{Ba}$ & $11.14 \mathrm{Ba}$ & $10.40 \mathrm{Bab}$ & $9.59 \mathrm{ABbc}$ & 10.21 \\
BARI Mung 6 & $8.55 \mathrm{Bbc}$ & $10.78 \mathrm{Bb}$ & $12.84 \mathrm{Aa}$ & $11.82 \mathrm{Bab}$ & $12.40 \mathrm{Aa}$ & $11.24 \mathrm{Aab}$ & 11.27 \\
Binamoog 5 & $7.48 \mathrm{Dc}$ & $8.61 \mathrm{Cb}$ & $10.23 \mathrm{Ca}$ & $9.31 \mathrm{BCab}$ & $9.71 \mathrm{Cab}$ & $8.37 \mathrm{Cbc}$ & 8.95 \\
\hline Mean & 9.43 & 10.99 & 12.27 & 11.64 & 11.31 & 9.79 & \\
\hline
\end{tabular}

Means followed by same small letter(s) (row) and capital letter(s) (column) did not differ significantly at $5 \%$ level of probability by DMRT.

\section{Conclusion}

Nodulation, nitrogen fixation and seed yield varied with mungbean genotypes and $\mathrm{N}$ rates. The IPSA 12 mungbean performed the best result at $40 \mathrm{~kg} \mathrm{~N} \mathrm{ha}{ }^{-1}$ application and the ACC12890053 did the lowest.

\section{References}

Akbari, N., M. Barani and H. Ahmadi. 2008. Change of grain protein content and correlations with other characteristics under planting pattern and starter $\mathrm{N}$ fertilizer of mungbean (Vigna radiata L. Wilczek). Am. Eurasian J.Agric. Environ. Sci. 4: 306-310.

Akther, M. S. 2005. Physiological differences in yielding ability of traditional and modern mungbean genotypes (Vigna radiata (L) Wilczek). A Ph D thesis submitted Department of Agronomy, BSMRAU, Gazipur.

Anjum, M. S., Z. I. Ahmed and C. A. Rauf. 2006. Effect of Rhizobium inoculation and nitrogen fertilizer on yield and yield components of mungbean. Int. J. Agric. and Biol. 8: $238-240$.

Asaduzzaman, M., M. F. Karim., M. J. Ullah and M. Hasunuzzaman. 2008. Response of mungbean (Vigna radiata) to nitrogen and irrigation management. Am. Eurosia J. Sci. Res. 3: 40-43.

Biswas, J. C and A, Hamid. 1989. Influence of carbofuran on leaf senescenes and nitrogen uptake of mungbean (Vigna radiata) Bangladesh J. Agric. 14: 261-267. 
Devi, J. M., T. R.Sinclair and V. Vadez. 2010. Genotypic variability among peanut (Arachis hypogea L. ) in sensitivity of nitrogen fixation to soil drying. Plant Soil. 330: 139-148.

Devi, M. J., T. R. Sinclair, S. E. beebe and I.M. Rao. 2013. Comparison of common bean (Phaseolus vulgaris L.) genotypes for nitrogen fixation tolerance to soil drying. Plant Soil. 364: 29-37.

Hossain, M. A., A. Hamid and Q. A. Khaliq. 2009. Performance of mungbean genotypes (Vigna radiata (L.) Wilczek) under suboptimal and optimal nitrogen levels. Bangladesh. Agron. J. 12: 5-15.

Jenner, C. F., T. D. Ugalde and D. Aspinall. 1992. The physiology of starch and protein deposition in the endosperm of wheat. Aust. J. Plant Physiol. 18: 211-226.

Jensen, E. S. 1987. Seasonal patterns of growth and nitrogen fixation in field grown pea. Plant and Soil. 101: 29-37.

Minchain, F. R., M. Becana and J. I. Sprent. 1989. Short term inhibition of legume $\mathrm{N}_{2}$ fixation by nitrates. 2 . Nitrates effects on nodule oxygen diffusion. Planta. 180: 46-52.

Mitra, S and M. C. Ghildiyal. 1988. Photosynthesis and assimilates partitioning in mungbean in response to source sink alterations. J. Agron and Crop Sci. 160: 303308.

Murakami, T., S. Siripin, P. Wadisirisuk, N. N. Boonkend, T. Yoneyama, T. Yokoyama and H. Imai, 1990. The nitrogen fixing ability of mungbean (Vigna radiata $(\mathrm{L})$ Wilczek). Procedings of the mungbean meeting. Chingmai, Thailand. February 23-24. Soil Science Division, Department of Agriculture, Bangkhen, Bangkok 10900, Thailand. Pp. 187-198.

Patra, F. M and L. R. Patel. 1991. Response of greengram varieties to phosphorus and rhizobium inoculation. Indian A. Agron. 36: 355-356.

Patra, D. K and P. Bhuttacharyya. 1997. Influence of root nodule bacterium on nitrogen fixation and yield of mungbean. J. Mycopathol. Res. 35: 47-49.

Poehlman, J. M. 1991. The Mungbean. Mohoni Primlani for Oxford and IBH Publishing Co. Pvt. Ltd. 66, Janapath road New Delhi 110001. P. 248.

Sagan, S., B. Ney and G. Duc. 1993. Plant symbiotic mutants as a tool to analyse nitrogen nutrition and yield relationship in field grown peas (Pisum sativum L.). Plant and Soil. 153: $33-45$.

Sinclair, T. R and V Vadez. 2002. Physiological traits for crop yield improvement in low $\mathrm{N}$ and $\mathrm{P}$ environments. Plant and Soil. 245: 1-15.

Walsh, K. B and B. J. Carroll. 1992. A reappraisal of nitrate inhibition of nitrogenease. A nitrate reductase-deficient mutant of pea (Pisum sativum). Physiol. Plant. 4: 283-291.

Warembourg E. R and C. Roumet. 1989. Why and how to estimate the cost of symbiotic $\mathrm{N}_{2}$ fixation? A progressive approach based on the use of the ${ }^{14} \mathrm{C}$ and ${ }^{15} \mathrm{C}$ isotopes. Plant and Soil. 115: 167-177. 